\title{
PLANKTON PRODUCTION BETWEEN THE YORKSHIRE COAST AND THE DOGGER BANK, I933-I939
}

\author{
By R. S. Wimpenny \\ Ministry of Agriculture and Fisheries
}

(Text-fig. I)

Between March 1933 and June $1939^{1}$ a series of vertical hauls with a plankton net has been made at a line of six stations 12 miles apart, the first lying off Flamborough Head and the last on the south-west patch of the Dogger Bank. This line was usually visited at monthly intervals, the net used being of the Hensen type fitted with bolting silk of 60 meshes to the inch and hauled to the surface by the counter-weight device introduced by BuchananWollaston (I9II). Hensen (I887) worked out a filtration coefficient for his net, and when this was applied to the dimensions of the one in use and the depth through which the vertical hauls were made, it was possible to express the catch in numbers per cubic metre of sea water. It was also possible to give the individual catches by weight, and it may not be without interest to observe, before passing on to deal with numbers, that the dry weights taken in 1936 varied between $0.2600 \mathrm{~g}$. per m. ${ }^{3}$ in August and 0.0015 in February.

Although the net method of estimating plankton has often been decried as unreliable, Hensen net results have always given a consistent picture of relative plankton densities in the North Sea. Confidence arising from this consistency has not been lessened by a comparison of the net and sedimentation methods which has been made in respect of the May 1938 samples.

The sedimentation method consists in counting the entire deposit of microplankton which has settled on the floor of a glass cell containing a known volume of sea water. The counting is done by the use of Utermöhl's reversed microscope. This method has been shown to be superior to that of centrifuging and gives the most complete direct estimation at present known (Nielsen, I933). The two sets of observations for May are shown on p. 2, the numbers being per cubic metre for the Hensen net and per litre for the sedimentation samples.

It will be seen that, while the sedimentation method reveals several thousand times the number of organisms per unit of volume, both methods agree in showing the stations of greater abundance at the ends of the line, although they disagree in showing the stations of greatest abundance at opposite ends.

1 The observations actually began in June 1932, but, owing to war conditions, the writer has not been able to examine the data from this earlier period. 

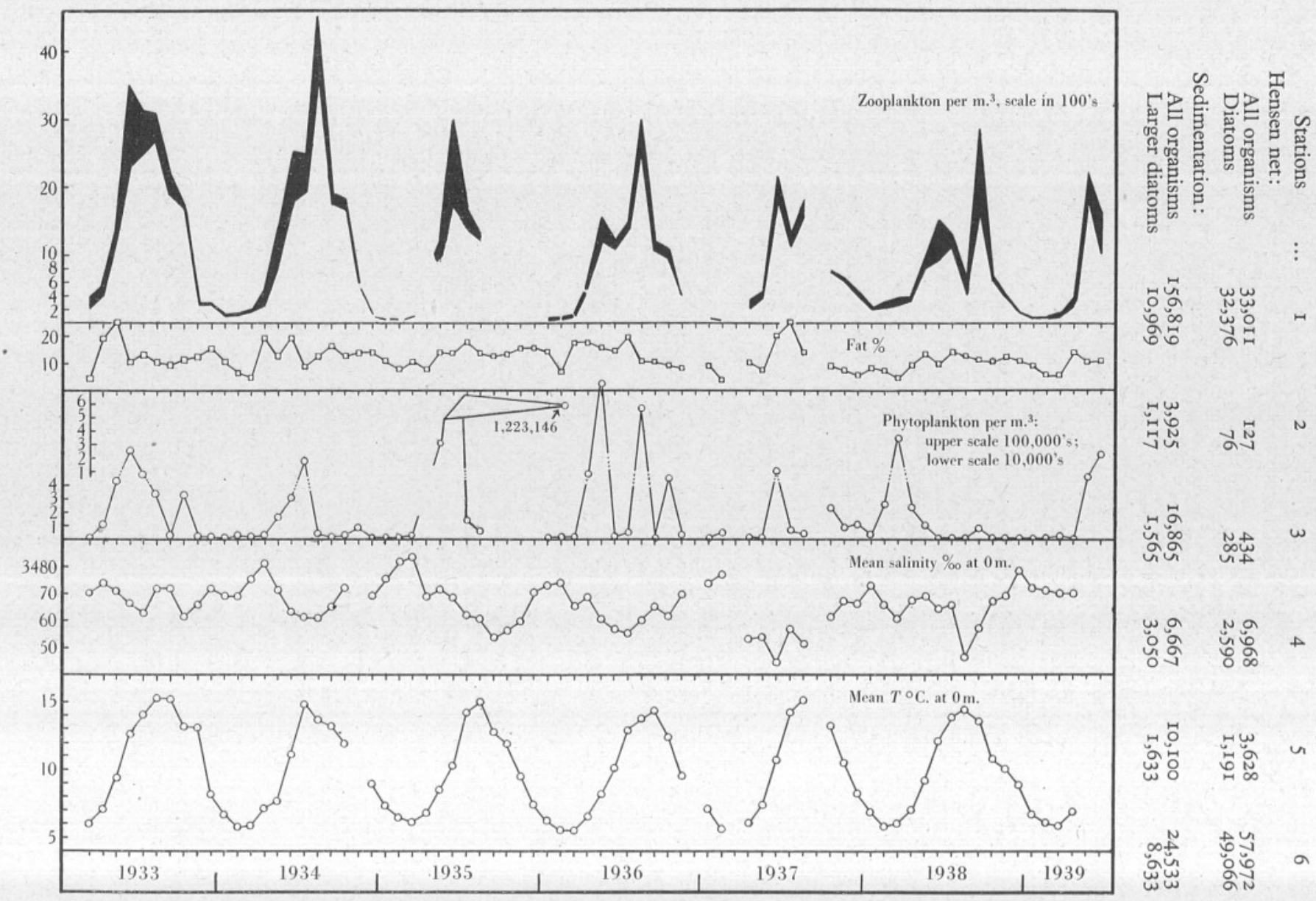

N

芯

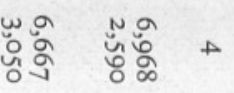

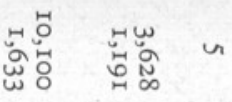

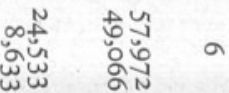

Fig. I. Mean monthly values at six stations between Flamborough Head and the Dogger Bank for zooplankton, plankton-fat, phytoplankton, salinity and temperature. 
The average catches per cubic metre, taking all the Flamborough line stations together, have been plotted at their monthly intervals in respect of zooplankton and phytoplankton in Fig. I. On the same figure are also shown the average percentage fat contents of dried net samples taken as duplicates of those used for enumeration.

The phytoplankton shown in the figure reached its highest values in 1935 and 1936, but otherwise it gives no indication of any special trend during the period and generally rises to a climax each year between May and June, often followed by a secondary maximum later in the year. The year 1938 was exceptional, however, in that the maximum occurred in March. In I936 the early maximum was succeeded by successively diminishing peaks in August and October.

In contrast to the phytoplankton, the zooplankton decreased through the period until 1937, after which it showed slight signs of a revival. Although during each year the zooplankton population appears to have built itself up on the corresponding phytoplankton maximum, the size of the stock so supported has little or no relation to the size of the phytoplankton standing crop revealed in the different years. The graph of the zooplankton has been split into upper and lower halves, the former showing the proportion of eggs and larvae. This representation suggests that reproduction must have been vigorous in 1933, I934 and 1935, but that it sank to a minimum in 1936 and I937, recovering again in 1938 and 1939.

The average for the six fat percentages taken each month and followed through the period shows a general downward trend. The annual cycle usually gives higher values in the first half of the year, and it seems likely that the fat percentage rises prior to the vigorous reproduction resulting in the zooplankton maxima.

Of the non-vital phenomena likely to form an explanatory background to the changes just described, salinity is probably the best index of certain relevant water movements now to be outlined. The stations from which the samples were taken lie across a submarine channel between Flamborough Head and the Dogger Bank. Down this channel the residual current system of the North Sea produces a south-going flow of water of higher salinity than that which it is about to enter. In this neighbourhood, it may be added, the south-going current is joining the western periphery of a circulation that usually flows in an anti-clockwise direction and is called the South-west Dogger Bank Swirl. The immediate origin of the south-going current is to be sought in oceanic water running into the northern entrance to the North Sea. It has been suggested elsewhere (Savage \& Wimpenny, I936) that an unusually strong incursion of oceanic water into the southern North Sea from the north also implies the convection of an increased supply of nutrient salts essential for diatom growth and this supply may form the foundation for especially abundant plankton production. Conditions of this sort are thought to have obtained in I92I and I933. 
Fig. I shows the course taken by the surface salinities of the Flamborough area for the period under review. Each year there appears to have been an impulse of water originating from the north. In the early part of the time, the salter water from the north reached the peak of its influence about April, but it tended to become earlier thereafter and by 1938 it occurred in January, the peak of the next maximum coming again in December of the same year instead of early the next year, as had previously been the case. There are, therefore, indications of a periodicity in the time of arrival of this water, the duration of which is less than a year. Considering next the salinities for the whole period shown in the figure, it is also to be observed that there is a progressive lowering in the values up to 1937 , indicating a slackening in the strength of the northern current and its fertile influence. During 1938 and 1939 a reversal of this process appears to have begun.

With regard to the minimum in 1937, it should be mentioned that observations taken over a wider area in October of the same year, which are being published elsewhere, revealed that the anti-clockwise direction of the South-west Dogger Bank Swirl had been reversed, the northern current entering the eastern periphery. A similar reversal has already been recorded for 1927 (Savage \& Hardy, 1935), and here it should be noted that, lying midway between I92I and I933, the northern influx might also be expected to have been low in 1927 .

The surface temperatures for the period are also plotted in Fig. I, but, beyond pointing out that 1936 is revealed as notably different from the other years in the lowness of both winter and summer values, no further comment need be made here.

The decrease and slight increase of salinities, during the period discussed, correspond so well with the sequence of abundance for the zooplankton that a significant relation suggests itself. Although at first sight this seems to be denied by the fact that no comparable sequence is shown by the phytoplankton, it is to be argued that the standing crop of phytoplankton is not necessarily a measure of its own production when the amounts eaten by zooplankton and the rate of growth are unknown. Indeed, the fact that a greater zooplankton population was supported in the earlier part of the period, whilst the standing crop of phytoplankton remained much the same at the close, implies a greater plankton production at the beginning. Given relations of this sort between the two plankton communities, it is even possible that the standing crop of phytoplankton may at times be in inverse relation to the zooplankton it supports and also to its own growth rate and the total production of plankton.

In connexion with this latter suggestion it may be noted that the results from very extensive samplings of the North Sea with the Hardy Continuous Recorder have led Lucas (I94I) to conclude that the phytoplankton throughout the southern North Sea increased between $1932-3$ and $1935-7$ but that since 1935-7 there had been a decrease- a state of affairs the opposite to that shown by the zooplankton dealt with in this account. 
It is, of course, possible that the zooplankton in the Flamborough neighbourhood has been behaving independently of the phytoplankton environment to be found in this area and has been responding to antecedent conditions which may be disclosed by the subsequent publication of data from a wider field. Moreover, in view of the degree of segregation and stability known to be associated with the diatom patches in the South-west Dogger Bank Swirl area, it is quite possible that the whole plankton of the Flamborough area may show a measure of independence in its fluctuations when compared with the North Sea as a whole. Nevertheless, I want to stress that the present observations and those made with the Hardy Continuous Recorder would be reconciled if it were considered that in the earlier part of the period the zooplankton of the North Sea had eaten down a more productive phytoplankton than became available for its support towards I937. As the zooplankton stock became reduced, it may be conceived to have permitted potentially weaker diatom flowerings to have assumed higher population densities and so have gradually resulted in the greater phytoplankton abundance indicated by Lucas.

In the northern North Sea salinities have revealed signs of predominating Atlantic influence from I93I, normal conditions not returning until 1939 (Fishery Board for Scotland, 1932-9), and, at the southern entrance, Carruthers's latest work on residual currents revealed by Lucas (I94I) indicates a hold-up or reversal of the current entering from the Channel between I93I and 1938 after which the flow towards the North Sea was resumed.

Outside the North Sea, Kemp (1938), quoting the work of Ford, Atkins, Cooper, and F. S. Russell, has pointed out that the herring fishery at Plymouth, the amount of winter phosphate and the numbers of young fish have all declined sharply in the Plymouth area since 1931. Here there is no apparent relation with the temperature and salinity, and Kemp considers this likely to be due to ignorance of the constitution and origin of the water masses which enter the Channel from time to time.

In the Arctic (Scherhag, 1937) an increase in temperature has taken place in recent years which has resulted in a great spread of the cod fishery.

The changes just mentioned deserve relation to those dealt with here, especially with a view to the determination of any periodicities in plankton production that may be forecast with advantage to the commercial fisheries; it is hoped that post-war observations will allow this aim to be realized.

My thanks are due to Dr E. S. Russell, Director of Fisheries Research, and Lt.-Commander J. R. Lumby of the Fisheries Laboratory, Lowestoft, for their helpful comments on the matter in this note. 


\section{REFERENCES}

Buchanan-Wollaston, H. J., I9II. Report on the results of the fish-egg cruise made by the S.S. 'Huxley' in June, 1909. Internat. Fish. Invest., Mar. Biol. Assoc., Report III (Southern Area), I906-8. H.M.S.O., London.

FISHERY BOARD FOR SCOTLAND, I932-9. Annual Reports for I93I-8. H.M.S.O., Edinburgh.

Hensen, V., I887. Über die Bestimmung des Planktons. Fahresber. Komm. wiss. Untersuch. deutsch. Meere. Kiel.

KEMP, S., I938. Oceanography and the fluctuations in the abundance of marine animals. Rep. Brit. Assoc. Adv. Sci. London, p. 85.

LuCAS, C. E., I94I. Phytoplankton in the North Sea, I938-9. Pt. I. Diatoms. Hull Bull. Mar. Ecol., No. 8, Vol. II, p. I9.

NIELSEN, E. S., I933. Úber quantitative Untersuchung von marinem Plankton mit Utermöhls umgekehrtem Mikroskop. Fourn. Cons. Int. Explor. Mer, Vol. vIII, p. 201.

SAVAGE, R. E. \& HaRdy, A. C., I935. Phytoplankton and the herring. Pt. I, I92 I-32. Min. Agric. E Fish., Fish. Invest., Ser. 2, Vol. xIv, No. 2.

Savage, R. E. \& Wimpenny, R. S., I936. Phytoplankton and the herring. Pt. II, I933 and 1934. Min. Agric. E Fish., Fish. Invest., Ser. 2, Vol. xv, No. I.

ScherHAG, R., I937. Die Erwärmung der Arktis. fourn. Cons. Int. Explor. Mer, Vol. xII, p. 263. 